\title{
Perancangan Multimedia Interaktif Pembelajaran Pengodean Penyakit Berdasarkan ICD-10
}

\author{
Dyah Alfiyatun Fitriani ${ }^{1}$, Nuryati $^{2}$ \\ Mahasiswa Diploma III Rekam Medis Sekolah Vokasi Universitas Gadjah Mada1 \\ Staf Pengajar Diploma III Rekam Medis Sekolah Vokasi Universitas Gadjah Mada ${ }^{2}$ \\ al.fitriani.fi@gmail.com ${ }^{1}$, nur3yati@yahoo.com ${ }^{2}$
}

\begin{abstract}
ABSTRAK
Latar Belakang: Perkembangan IPTEK yang pesat mendorong semua aspek kehidupan mengalami perubahan termasuk pembelajaran. Masih banyak mahasiswa rekam medis yang kesulitan dalam mempelajari pengkodean penyakit, padahal nantinya perekam Medis harus memiliki kompetensi tersebut. Menyikapi adanya perkembangan teknologi dan kesulitan dalam mempelajari pengodean penyakit tersebut, mendorong untuk membuat suatu multimedia interaktif terkait pembelajaran pengodean penyakit berdasarkan ICD-10.

Tujuan: Menghasilkan multimedia interaktif pengodean penyakit bagi mahasiswa rekam medis pada bab tersulit dalam ICD-10.

Metode: Perancangan ini menggunakan metode pengembangan multimedia menurut Luther dengan ICD 10, modul Praktik Klasifikasi dan Kodefikasi Penyakit dan Masalah Terkait (PKKPMT). dan Kamus Kedokteran Dorlan sebagai objek. Perancangan multimedia interaktif ini didasari oleh hasil survey terhadap mahasiwa rekam medis UGM dan wawancara dengan dosen PKKPMT. Perancangannya menggunakan Adobe Flash CS6.

Hasil: Hasil dari perancangan berupa multimedia interaktif pengodean penyakit yang berisi rule, terminologi, struktur ICD-10, contoh soal dan latihan soal. Perancangan menggunakan lima tahap yaitu pembuatan konsep, desain, pengumpulan bahan, assembly, testing dan distribusi.

Kesimpulan: Setelah dilakukan perancangan, bab yang paling sulit dalam ICD-10 menurut mahasiwa D3 Rekam Medis SV UGM adalah Bab XV tentang kehamilan, persalinan dan masa nifas. Perancangan multimedia interaktif pengodean penyakit berdasarkan ICD-10 membutuhkan isi berupa berupa rule bab XV, struktur ICD-10 bab XV, terminologi, contoh soal dan latihan soal yang dirancang dengan Adobe Flash CS6 dengan tahapan perkembangan multimedia menurut Luther (1994). Multimedia interaktif telah diuji cobakan kepada mahasiswa D3 Rekam Medis SV UGM dengan respon multimedia pengodean penyakit berdasarkan ICD-10 bisa dimanfaatkan pada mata kuliah praktek pengodean penyakit.
\end{abstract}

Kata kunci: perancangan, multimedia, pengodean penyakit, pembelajaran.

\begin{abstract}
Background: In this modern era, technology make everything changes and education is one of them. Many medical record students found difficulties to understood codification of diseases, even though medical recorder is expected to have more competencies to code many kinds of disease that very important. This problem leads the researcher to develop interactive learning to help them to have better understanding in coding disease based on ICD-10.

Objective: To design interactive multimedia codification of disease for medical record students in the most difficult chapter on ICD-10.

Methods: Method using multimedia development by Luther with ICD-10 and Practice Classification and Codification of Disease of Related Health Problem handbook (PKKPMT module) and Dorland's Illustrated Medical Dictionary as object design. This design is constituted to the result of medical record students survey and PKKPMT lecture interview. The design used Adobe Flash CS6 as developing tool. Result: Interactive multimedia codification of diseases was made. The contents such us rule, terminology, structure ICD-10, example and test. The multimedia development method consisted of six steps, namely: concept, design, material collecting, assembly, testing and distribution.

Conclusion: After completing the design, found that Chapter $X V$ which explains pregnancy, childbirth and puerperium is the most difficult part in ICD-10 based on medical recorder students SV UGM. In designing this interactive multimedia, needed contents such as are rules and ICD-10 structure of Chapter $X V$, terminology and some exercise together with the examples. Students had better understand in codification disease based on ICD-10 after using this multimedia.
\end{abstract}

Keywords: Codification, Design, Interactive Learning, Multimedia. 


\section{PENDAHULUAN}

Perkembangan IPTEK yang sangat pesat sekarang ini mendorong semua aspek kehidupan ikut mengalami perubahan tak terkecuali dalam bidang ilmu kesehatan dan pendidikan. Menurut Mukhtar dan Iskandar (2010), dunia pendidikan saat ini dituntut lebih adaktif terhadap perkembangan teknologi. Berbagai pendekatan pembelajaran melalui media berbasis komputer atau Computer Based Instruction (CBI) seperti drill and practice, simulasi, tutorial, dan permainan. Menurut Fauzi (2013) salah satu pengembangan media pembelajaran dari teknologi informasi dan komunikasi adalah multimedia. Dengan pemanfaatan teknologi computer untuk mendukung kegiatan pembelajaran diharapkan dapat membantu memecahkan masalah belajar. Menurut Turban dkk dalam Suyanto (2004) multimedia adalah kombinasi dari paling sedikit dua media input dan output dari data. Media ini dapat berupa audio, animasi, video, teks, grafik dan gambar.

Menurut Peraturan Menteri Kesehatan Republik Indonesia Nomor 55 Tahun 2013 tentang Penyelenggaraan Pekerjaan Perekam Medis, perekam medis mempunyai kewenangan yang disebutkan pada pasal 13 yaitu melaksanakan sistem klasifikasi klinis dan kodefikasi penyakit yang berkaitan dengan kesehatan dan tindakan medis sesuai terminologi medis yang benar. Sejak tahun 1996 hingga saat ini kodefikasi atau pengodean penyakit di Indonesia diseragamkan dalam panduan International Statistical Classification of Diseases and Related Health Problems (ICD) adalah system klasifikasi yang komperhensif dan diakui secara internasional (Hatta, 2013). Di Indonesia pemberlakuan ICD-10 sebagai pedoman klasifikasi penyakit telah diatur dalam Keputusan Menteri Kesehatan RI No.50/MENKES/SK/I/1998 yaitu tentang Pemberlakuan Klasifikasi Statistik Internasional Mengenai Penyakit Revisi ke10 tertanggal 13 Januari 1998. ICD-10 berisi klasifikasi penyakit terkait morbiditas dan mortalitas. WHO telah membuat ICD-10 training yang dapat diakses melalui web secara online di http://apps. who.int/classifications/apps
/icd/icd10training/ICD10\%20training/St art/inde $x$.html.

Aplikasi pembelajaran tersebut memuat beberapa menu modul ICD-10 berupa pengenalan ICD-10, struktur ICD10 , rule dan petunjuk kode mortalitas dan morbiditas yang disedikan secara lengkap dalam bahasa inggris. Di Indonesia, perancangan aplikasi pembelajaran pengodean penyakit pernah dibuat oleh Nuryati. Aplikasi pembelajaran yang tersebut berisi modul ICD-10, modul anatomi dan fisiologi, modul kamus kedokteran dan kuis yang bisa diakses dengan web browser. Tetapi sangat disayangkan aplikasi tersebut belum dimaksimalkan.

Sesuai dengan kurikulum yang diterapkan di UGM, klasifikasi dan kodefikasi penyakit dibagi menjadi dua yaitu mata kuliah teori dan praktik. Pada mata kuliah praktik memiliki jumlah 15 sks dan pada mata kuliah teori memiliki 11 sks yang harus ditempuh oleh mahasiwa dari semester satu hingga semester lima. Saat ini praktik pengodean penyakit masih dianggap sulit oleh sebagian mahasiswa. Berdasarkan survey sebanyak $66 \%$ mahasiswa mengatakan pengodean penyakit memiliki tingkat kesulitan sedang, 26\% mahasiwa mengatakan pengodean penyakit sulit dan $8 \%$ mahasiwa mengatakan pengodean penyakit mudah. Oleh karena itu, untuk menunjang begitu pengtingnya pengodean penyakit bagi profesi perekam medis, pemanfaatan tegnologi informasi dalam pembelajaran dan mengikikis paradigma yang sulit dalam pengodean penyakit perlu adanya perancangan multimedia interaktif. Multimedia interaktif yang dapat digunakan sebagai alat bantu pembelajaran pengodean penyakit tanpa harus bertatap muka dengan instruktur dan dapat diakses melalui dekstop. Tujuan Perancangan Menghasilkan multimedia interaktif pembelajaran pengodean penyakit bagi mahasiswa rekam medis pada bab tersulit dalam ICD-10. Manfaat Perancangan:

1. Bagi institusi pendidikan

Hasil perancangan ini diharapkan dapat dipergunakan sebagai instrumen 
yang bermanfaat dalam pengembangan ilmu pendidikan

2. Bagi rumah sakit/puskesmas

Hasil perangcangan ini diharapkan dapat membantu para koder ataupun Perekam Medis Informasi Kesehatan (PMIK) dalam melatih mengkode penyakit.

3. Bagi perancang

Hasil perancangan ini diharapkan dapat mengingkatkan wawasan dan memperbanyak pengetahuan terkait pembuatan aplikasi berbasis flash yang dapat diaplikasikan dalam ilmu rekam medis.

4. Bagi mahasiswa rekam medis

Hasil perancangan ini diharapkan dapat membantu dalam proses pembelajaran pengodean penyakit.

\section{METODE PERANCANGAN}

Perancangan ini menggunakan metode action research dengan ICD-10, modul Praktik Klasifikasi dan Kodefikasi Penyakit dan Masalah Terkait (PKKPMT) dan Kamus Kedokteran Dorlan sebagai objek. Perancangan multimedia interaktif ini didasari oleh hasil survey terhadap mahasiwa rekam medis UGM dan wawancara dengan dosen PKKPMT. Perancangannya menggunakan applikasi Adobe Flash CS6. Dikutip dari Overview of the Adobe Flash Professional CS6 Workspace, Adobe Flash Creative Suite 6 (CS6) merupakan sebuah software yang didesain khusus oleh Adobe dan program aplikasi standar authoring tool professional yang digunakan untuk membuat animasi dan bitmap yang sangat menarik untuk keperluan pembangunan situs web yang interaktif dan dinamis. Perancangan multimedia ini menggunakan tahap perkembangan multimedia menurut Luther yaitu consept, design, material collection, assembly, testing dan distribution yang telah dimodifikasi.

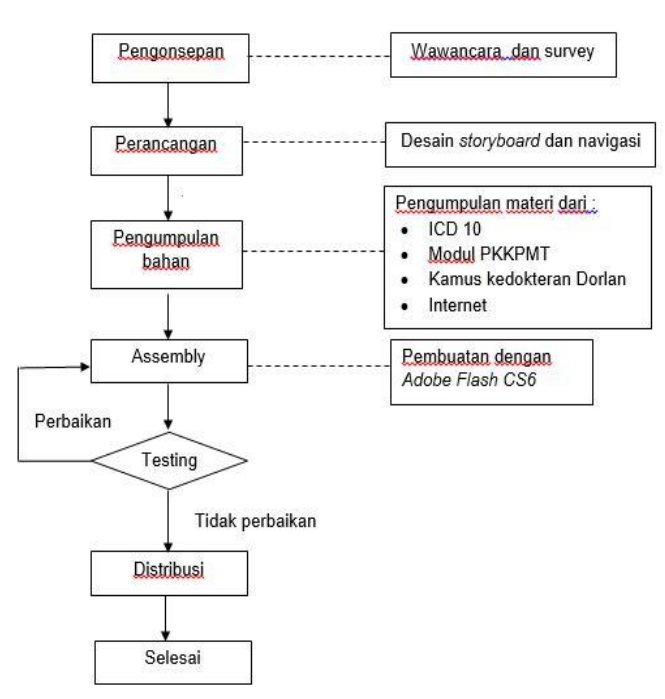

Gambar 1. Kerangka Konsep Perancangan

\section{HASIL DAN PEMBAHASAN}

Pembuatan perancangan multimedia interaktif pengodean penyakit berdasarkan ICD-10 dilaksanakan sesuai langkah-langkah sebagai berikut:

1. Tahap Konsep (Concept)

Berdasarkan hasil survey diperoleh bahwa tulisan dokter, terminologi medis, stuktur ICD-10 dan rule adalah hal yang membuat pengkodean penyakit sulit. Hasil wawancara dengan informan mengatakan bahwa dalam penyampaian dan pembelajaran perlu adanya gambar atau peraga agar mahasiwa paham tidak hanya mengubah diagnosis tersebut menjadi kode tetapi juga paham maksud dari diagnosis tersebut. Hal lain yang diperlukan terkait pengkodean penyakit yaitu rule, terminologi, stukrur ICD-10, anatomi dan latihan soal yang variatif. Hasil survey terhadap mahasiswa menyatakan bahwa bab yang paling sulit adalah bab XV. Berdasarkan hasil survey dan wawancara dengan informan maka dibuat perancangan multimedia interaktif pengkodean penyakit berdasarakan ICD-10 yang berfokus pada bab XV dengan menggunakan aplikasi Adobe Flash CS6. Hasil multimedia yang dibuat dalam aplikasi ini dapat dibuka dengan menggunakan flash player dan web browser seperti Mozilla Firefox, Opera dan Internet Explore tanpa 
menggunakan koneksi internet. Selain itu bisa langsung dibuka pada semua komputer/ laptop tanpa menginstal program terlebih dahulu dengan membuka multimedia yang telah berekstensi .exe. Berikut kerangka pengonsepan multimedia.

\section{Tabel 1. Konsep Multimedia Bab XV}

\begin{tabular}{l|l}
\hline Judul & $\begin{array}{l}\text { Aplikasi Pembelajaran Koding } \\
\text { Penyakit berdasarkan ICD-10 } \\
\text { (APELKOD-10) }\end{array}$ \\
Audiens & $\begin{array}{l}\text { Mahasiswa Rekam medis } \\
\text { Durasi } \\
\text { Tidak terbatas } \\
\text { Struktur ICD-10 bab XV, spesial note } \\
\text { bab XV, anatomi terkait termonologi } \\
\text { bab XV, tulisan dokter dan formulir } \\
\text { RM }\end{array}$ \\
Interaktif & $\begin{array}{l}\text { Disetiap halaman terdapat navigasi } \\
\text { untuk link kehalaman berikutnya } \\
\text { dan latihan soal } \\
\text { Membantu dalam belajar pengodean } \\
\text { Tujuan }\end{array}$ \\
\hline
\end{tabular}

\section{Tahap Design}

Tahap desain dilakukan dengan merancang storyboard dan racangan navigasi. Rancangan storyboard dan navigasi dirancang berdasarkan adapasi dari rancangan storyboard Chasannah (2009).

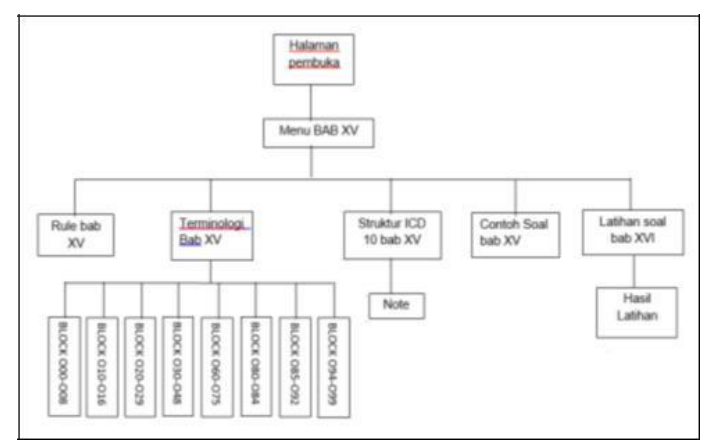

Gambar 2. Rancangan Navigasi

3. Tahap pengumpulan bahan (material collection)

Pada tahap pengumpulan bahan yang diperlukan dalam isi multimedia sesuai dengan kebutuhan user. Pengumpulan bahan bersumber dari ICD-10, modul PKKPMT, kamus kedokteran Dorland dan internet. Bahan yang diperlukan berupa materi (teks), gambar, video, animasi dan audio.
4. Tahap assembly

$\begin{array}{ccc}\text { Tahap } & \text { assembly untuk } \\ \text { pertamakali } & \text { melakukan desain }\end{array}$ interface pada stage yang telah tersedia pada applikasi Adobe Flash CS6 sesuai dengan storyboard dan navigasi yang telah dirancang sebelumnya. Setelah desain interface selesai dibangun maka tahap selanjutnya adalah dengan memberikan kode syntax di actionscript pada setiap frame yang telah dibuat sehingga desain interface pada stage bisa dijalankan.

\section{Tahap testing}

Tahap testing dilakukan dengan uji coba pada kelompok besar. Langkah testing yaitu uji betha yang dilakukan pada mahasiwa rekam medis. Testing dilakukan dengan perancang masuk ke dalam kelas-kelas sebelum kelas praktik pengodean dimulai. Pada saat melakukan testing tidak semua mahasiswa dalam sekelas mengikuti, sehingga testing dilakukan dengan kelompok terfokus (focus group) berjumlah kurang lebih delapan orang per kelas. Jumlah kelas yang dilakukan testing ada empat kelas yang dipilih secara acak. Tahap testing ini perancang melakukan pengenalan terlebih dahulu terhadap multimedia yang sudah dibuat, melakukan demo penggunaan multimedia dan menyebarkan kuesioner.

Hasil kuesioner terkait kemudahan dalam pemakaian multimedia $\quad 86,67 \% \quad$ responden menyatakan mudah dalam pemakaian aplikasi dan sisanya 13,33\% menyatakan sedang dari keseluran responden yang berjumlah 30 orang. Dengan demikian multimedia interaktif pengodean penyakit berdasarkan ICD-10 mudah dalam pemakainnya.

Hasil kuesioner terkait materi yang ada dalam multimedia sudah mencakup materi dalam mempelajari pengodean penyakit $16,67 \%$ responden menyatakan materi dalam multimedia sudah sangat mencakup keseluruhan materi, $80 \%$ responden menyatakan materi dalam multimedia cukup 
mewakili dalam mempelajari pengodean penyakit, 3,33\% responden menyatakan materi dalam multimedia kurang mewakili materi dalam mempelajari pengodean penyakit dari keseluruhan responden yang berjumlah 30 orang. Dengan demikian materi yang terdapat dalam multimedia interaktif pengodean penyakit berdasarkan ICD-10 cukup mewakili dalam mempelajari praktik pengodean penyakit.

Hasil kuesioner terkait perancangan multimedia pengodean penyakit memberi efek kemudahan dalam mempelajari praktik pengodean penyakit dengan aplikasi multimedia, $36,67 \%$ responden menyatakan sangat memberi efek kemudahan, 63,33\% responden menyatakan cukup memberikan efek kemudahan dari keseluruhan responden berjumlah 30 orang. Dengan demikian perancangan multimedia interaktif pengodean penyakit berdasarkan ICD-10 pengodean penyakit cukup memberikan efek kemudahan dalam mempelajari praktik pengodean penyakit.

Hasil kuesioner terkait interaktifan multimedia, $\quad 36,67 \% \quad$ responden menyatakan multimedia pengodean penyakit sangat interaktif, 53,33\% responden menyatakan cukup interaktif dan $10 \%$ responden menyatakan kurang interaktif. Dengan demikian multimedia pengodean penyakit berdasarkan ICD-10 cukup bersifat interaktif.

Selain dari hasil kuesioner, perancang juga menampung saran dari responden terkait perbaikan multimedia. Berikut sampel hasil kutipan yang dari responden:

"Contoh soal diperbanyak dan dikasih penjelasan dan kunci jawaban diakhir"

\section{Responden 3,4,7}

"Jumlah soal mungkin bisa ditambah, jadi semisal setelah mengerjakan dan logout bisa mendapat soal yang berbeda" Responden 1
"Materinya ditambah lagi sama terminologinya ditambah juga". Responden 12,11,20,9

"Videonya ditambah, ditambah animasi sama suara biar lebih menarik"Responden 8 "Ditambahkan bullet atau dikasih bold pada terminologinya biar enak dibaca"

\section{Responden 1,5}

"Warna interface diganti biar enak dilihat" Responden 3

"Sudah bagus dan buat untuk bab lainnya juga". Responden 14,15,17

Hasil wawancara kembali dengan informan masih perlu banyak perbaikan terkait multimedia yaitu penambahan penjelasan dan contoh pada rule, penambahan dan pengelompokan termonologi berdasarkan blok, penambahan struktur ICD-10, penambahan pilihan jawaban dan perbaikan warna tampilan.

Pada tahap testing masih perlu perbaikan berdasarkan hasil wawancara kembali dengan informan dan saran yang berasal dari responden. Perbaikan yang telah dilakukan berupa mengganti warna interface agar tidak terlalu mencolok, penambahan source pada setiap video dan gambar yang ada dalam multimedia serta penambahan page of pada setiap halaman. Perbaikan yang telah dilakukan terkait isi dalam multimedia berupa penambahan terminology bab XV, penambahan contoh dan penjelasan dari setiap rule terkait bab XV, penambahan note pada setiap blok bab XV, penjelasan struktur ICD-10 setiap blok pada bab XV dan penambahan opsi jawaban pada latihan soal. Perbaikan telah dilakukan untuk penyempurnaan multimedia kemudian dilakukan tahap distribusi.

6. Tahap distribution $\begin{array}{cll}\text { Tahap } & \begin{array}{l}\text { distribution } \\ \text { merupakan } \\ \text { tahap }\end{array} \text { produk } & \text { multimedia }\end{array}$ pembelajaran telah siap dipakai dan digunakan sebagai sumber belajar. Pada tahap ini dilakukan setelah multimedia diperbaiki berdasarkan hasil wawancara kembali dengan informan dan saran dari responden. 
Multimedia yang telah siap pakai dapat digunakan user/pengguna yaitu mahasiswa rekam medis UGM sebagai alat bantu pembelajaran pengodean secara mandiri yang dapat diakses melalui laptop/komputer. Cara penggunaan multimedia ini user membuka file Apelkod dalam bentuk .zip/.rar kemudian diekstrak, setelah file terekstrak user membuka aplikasi yang berbentuk apelkod.exe kemudian user sudah bisa menggunakan aplikasi tersebut, pada menu latihan soal user perlu mempersiapkan ICD-10 dalam bentuk buku atau bentuk elektronik sebagai alat bantu dalam mengerjakan. latihan. Berikut gambaran garis besar hasil akhir perancangan multimedia pengodean penyakit berdasarkan ICD10.

Berikut gambaran garis besar hasil akhir dari perancangan:

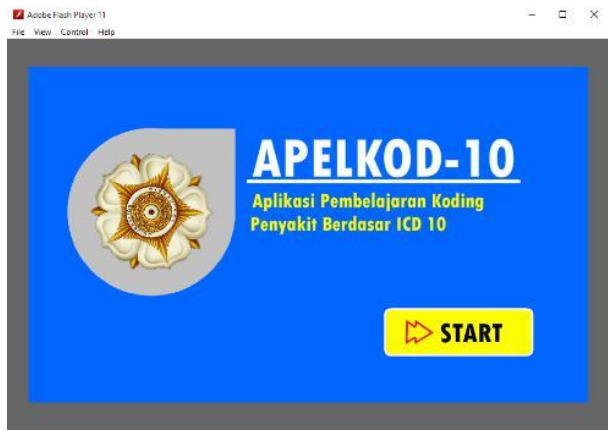

Gambar 3. Halaman pembuka

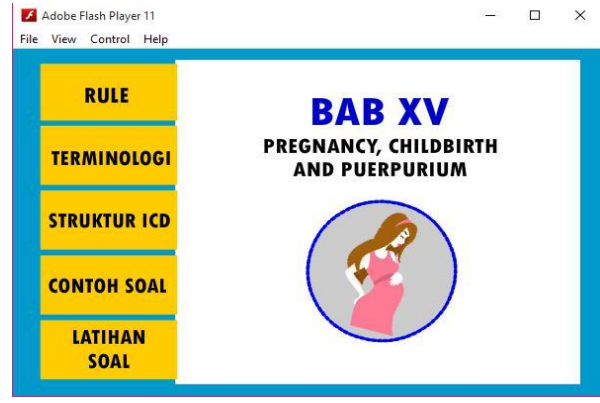

Gambar 4. Menu Utama

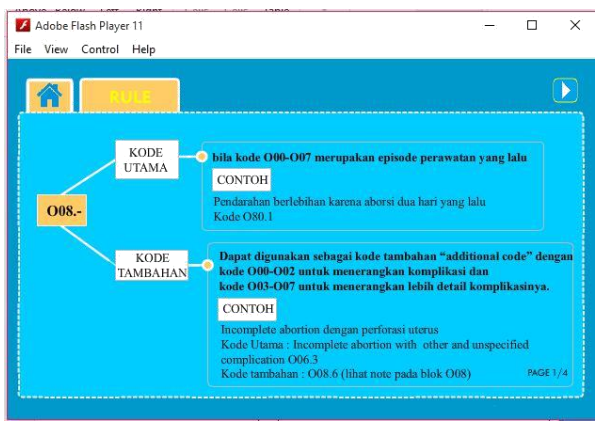

Gambar 5. Rule

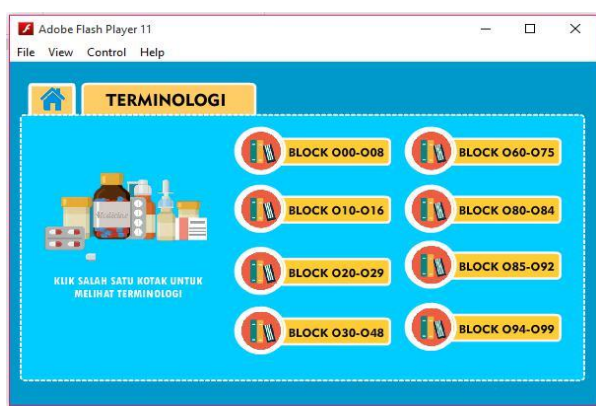

Gambar 6. Terminologi

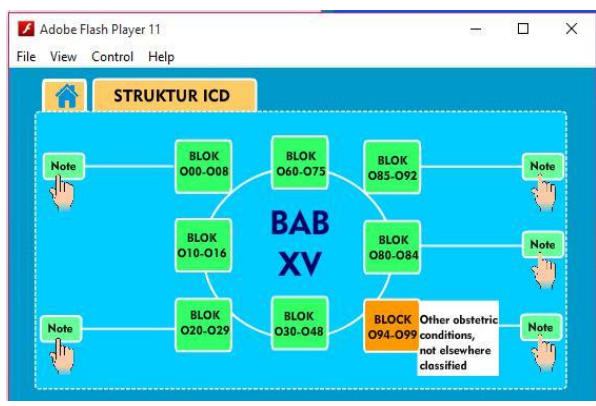

Gambar 7. Struktur ICD-10

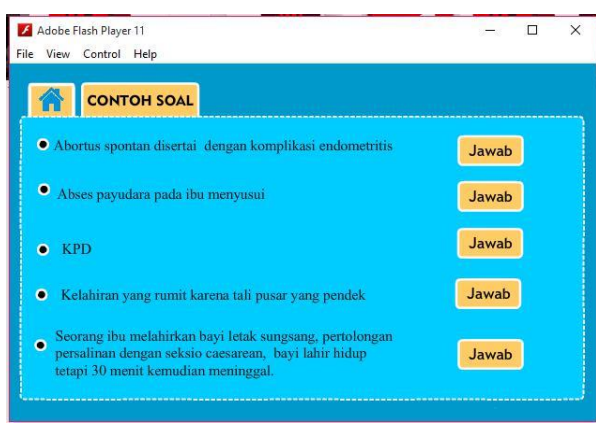

Gambar 8. Contoh Soal

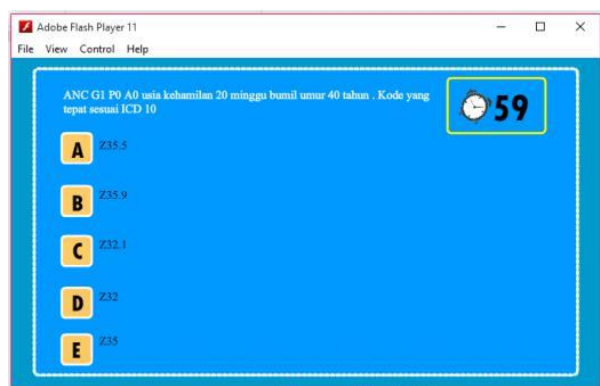

Gambar 9. Latihan Soal

\section{PENUTUP}

Setelah dilakukan perancangan bab yang paling sulit dalam ICD-10 menurut mahasiwa D3 Rekam Medis SV UGM adalah Bab XV tentang kehamilan, persalinan dan masa nifas. Perancangan multimedia interaktif pengodean penyakit berdasarkan ICD-10 membutuhkan isi berupa berupa rule bab XV, struktur ICD10 bab XV, terminologi, contoh soal dan latihan soal yang dirancang dengan applikasi Adobe Flash CS6 dengan tahapan perkembangan multimedia menurut 
Luther (1994). Multimedia interaktif telah diuji cobakan kepada mahasiswa D3 Rekam Medis SV UGM dengan respon multimedia pengodean penyakit berdasarkan ICD-10 cocok dalam membantu mata kuliah praktek pengodean penyakit.

\section{SARAN}

Hasil perancangan multimedia interaktif pengodean penyakit dapat digunakan mahasiwa rekam medis sebagai alat bantu pembelajaran dengan penambahan link ICD-10 dan perlu adanya perancangan multimedia atau aplikasi multimedia pembelajaran pengodean penyakit terkait bab-bab lain dalam ICD-10 maupun ICD 9 CM.

\section{DAFTAR PUSTAKA}

Adobe Systems Incorporated. (2012). Overview of the Adobe Flash Professional CS6 Workspace. http://Www.georgetownisd.org/cms /lib/TX01001838/Centricity/Domain /781/cs6_p5_flash_workspace.pdf. Diakses tanggal 28 Maret 2017.

Chasanah. (2009). Pembuatan Media Pembelajaran Interaktif Fisika Pokok Bahasan Suhu dan Kalor dengan Macromedia Flash. Tesis. Universitas Gadjah Mada.

Fauzi. (2013). Pengembangan Multimedia Pada Pembelajaran Muatan Lokal Batik di SMK Negeri 4 Yogyakarta. Skripsi. Universitas Negeri Yogyakarta.

Hatta, G. (2013). Manajemen Informasi Kesehatan di Sarana Pelayanan Kesehatan. Jakerta: UI Press.

Keputusan Menteri Kesehatan RI No.50/MENKES/SK/I/1998 tentang Pemberlakuan Klasifikasi Statistik Internasional Mengenai Penyakit Revisi ke-10 tertanggal 13 Januari 1998. www.depkes.go.id. Diakses tanggal 1 Mei 2017.

Mukhtar dan Iskandar. (2010) Desain Pembelajaran Berbasis Teknologi Informasi dan Komunikasi (Sebuah Orientasi Baru). Jakarta: Gaung Persada (GP) Press Jakarta.

Nuryati. (2015). Pemanfaatan Teknologi Informasi dalam Pembelajaran
Klasifikasi \& Kodefikasi Penyakit dan Masalah Terkait. JMIKIVol 3 (1).

Peraturan Menteri Kesehatan RI No 55 tahun 2013 tentang Pentelenggaraan Pekerjaan Perekam Medis. www.depkes.go.id. Diakses tanggal 1 Januari 2017.

Sutopo. (2003). Multimedia Interaktif Dengan Flash. Yogyakarta: Graha Ilmu.

Suyanto. (2004). Analisis dan Desain Aplikasi Multimedia untuk Pemasaran. Yogyakarta: Andi Offset.

World Health Organization. (2010). International Statistical of Disease and Related Health Problem Tenth Revision (ICD-10). Geneva: World Health Organization. 